\title{
Design of constant output voltage DC-AC inverter for batteryless solar PV system
}

\author{
Agus Risdiyanto, Bambang Susanto, Noviadi Arief Rachman, Anwar Muqorobin, \\ Tinton Dwi Atmaja, Harjono P. Santosa \\ Research Center for Electrical Power and Mechatronics, Indonesia Institute of Sciences, Indonesia
}

\begin{tabular}{|c|c|}
\hline Article Info & ABSTRACT \\
\hline Article history: & This paper introduces a DC-AC inverter design that operates stand alone to \\
\hline Received Nov 20, 2019 & $\begin{array}{l}\text { deliver power from solar photovoltaic (PV) to the load directly without going } \\
\text { through the battery. In batteryless solar PV, the output voltage of solar PV }\end{array}$ \\
\hline Revised Feb 9, 2020 & always varies according to solar irradiation, temperature, so that it becomes a \\
\hline Accepted Mar 23, 2020 & $\begin{array}{l}\text { challenge in modelling DC-AC inverter with constant output voltage. The } \\
\text { design consists of a boost converter, h-bridge switching and driver, and LC }\end{array}$ \\
\hline Keywords: & $\begin{array}{l}\text { filter to generate sinusoidal ac voltage as output to load. To ensure a constant } \\
\text { inverter output voltage, the design equipped by a close loop PI controller }\end{array}$ \\
\hline Batteryless & based on voltage control mode. The design modelled and simulated by PSIM. \\
\hline Constant voltage & PV dc input was set variation according to the irradiation value $\left(\mathrm{W} / \mathrm{m}^{2}\right)$ and \\
\hline $\mathrm{DC}-\mathrm{AC}$ inverter & $\begin{array}{l}\text { the output connected to a load that has rated voltage of } 220 \mathrm{Vac} \text { and } 3.4 \mathrm{~A} \text { of } \\
\text { nominal current. The results show that in the irradiation variation } 600-1500\end{array}$ \\
\hline Efficiency & $\mathrm{W} / \mathrm{m}^{2}$, the inverter was able to maintain the output voltage of $220 \mathrm{Vac} \pm$ \\
\hline Photovoltaic & $\begin{array}{l}0.91 \%, 50 \mathrm{~Hz} \text { which is still in the voltage range based on standard. The } \\
\text { efficiency produced by DC-AC inverter } 97.7 \% \text { at } 600 \mathrm{~W} / \mathrm{m}^{2} \text { and } 83.6 \% \text { at } \\
1500 \mathrm{~W} / \mathrm{m}^{2} \text {. }\end{array}$ \\
\hline
\end{tabular}

This is an open access article under the CC BY-SA license.

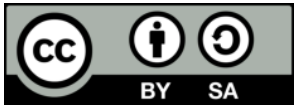

\section{Corresponding Author:}

Agus Risdiyanto,

Research Center for Electrical Power and Mechatronics,

Indonesian Institute of Sciences, Indonesia.

Email: riesdian@gmail.com

\section{INTRODUCTION}

Utilization of solar PV or solar cells as energy resources are increasingly being discussed over last decade. This technology is considered as an alternative source of environmentally friendly energy that is expected to replace conventional energy sources based on petroleum and coal. In electricity production, solar PV plays an important role because it is widely available in almost all parts of the world, clean, reliable, and scalable. The existence of government support in electricity utilization based on renewable energy and technological improvements can stimulate the use of solar PV more affordable for the future $[1,2]$.

Solar PV converts solar energy into dc electrical current with low dc output voltage. Generally the use of solar PV must still be integrated with other equipment such as solar charger controller (SCC), batery and inverter to supply household electrical appliances that mostly use large ac voltage according to utility grid voltage $(220 \mathrm{Vac}, 50 \mathrm{~Hz})$, [3-6]. The dc voltage generated by solar PV is always changing every time due to the irradiation and ambient temperature impacts that affect the power produced. In order for the efficiency of power generated by solar PV match with the load impedance in all weather conditions, it's required the maximum power point tracking (MPPT) performance by DC-DC converter [7]. Through MPPT the power fluctuation from solar PV can be easily stored into the battery, then through 
the DC power the inverter is stored in the battery with a stable voltage channeled to AC loads that are used for night or daytime purposes. Because the average low voltage of solar PV output, it requires a dc-dc boost converter from single stage even up to two stages if the gain is unreachable due to limited of duty cycle which affects to inconvenient in mosfets switching [8,9]. Solar PV installation system which each panel connected in series also able to considered and provides an output voltage of nearly voltage of utility grid. Therefore, if the input voltage of the solar PV already high, it only requires dc-dc converter in a single stage that gives numerous advantage such as simple topology and more efficient [10].

In the case of the use of solar PV to supply residential electric power, the development of power electronics technology today has resulted in more advanced and effective solar inverters named grid tie inverters (GTI). GTI is an inverter that output is directly connected to the utility grid (on-grid) and input is directly connected to solar PV or another renewable energy resources. It offers more advantages than stand alone inverter (off-grid). Generally, GTI was built without battery as power storage and input voltage. It can be eliminated due to considerations of cost reduction, less space, lighter, and easier maintenance [11]. However for safety reasons in utility grid, the GTI can not work to deliver power from PV when the utility grid shut down even in the daytime. It cannot be used for remote areas where utility grid really not available. Therefore, in recent years the application of solar PV in off-grid areas still often required such as in water pumpung systems [12].

In this study, the design of DC-AC inverter for standalone application (off-grid) was built with input voltage connected directly to solar PV without using batteries as energy storage with consideration of reducing costs, simpler maintenance, lighter and reducing space. The output of DC-AC inverter connected to constant specific loads that are only required during the day to solve the problem of power availability in deserts, farm, forest, and for the working of agricultural pump, air conditioner, fan loads, motor equipments and other electrical products. Specification solar PV refers to the module that existing in the market (Sharp ND-130T1J). The inverter output according to the allowable voltage standards based on the network utility of $220 \mathrm{Vac}(5 \%), 50 \mathrm{~Hz}$, with the load current determined constant $3.4 \mathrm{~A}$ (assuming the load power is $1 \mathrm{HP}=746 \mathrm{~W})$.

\section{PROPOSED SYSTEM DESIGN}

The system design consists of a dc-dc boost converter to increase the dc voltage of the PV output, h-bridge switching and its driver to convert dc to ac. To generate the sinusoidal ac output according to standard $(220 \mathrm{Vac}, 50 \mathrm{~Hz})$, SPWM technique implemented in mosfet driver, then LC filter used to minimized the ripple and harmonic content. To ensure a constant output voltage, the design equipped by a close loop of voltage control mode. The block diagram of proposed system is as shown in Figure 1.

In accordance with the block diagram in Figure 1, it can be explained that the system does not require battery as energy storage or to provide a stable inverter input voltage source as like most off-grid solar systems. The power generated from solar PV is used to supply loads that are only required during the day while supplying power to operate the controller. Further explanation regarding the components that make up the system above is discussed in the following sub chapters.

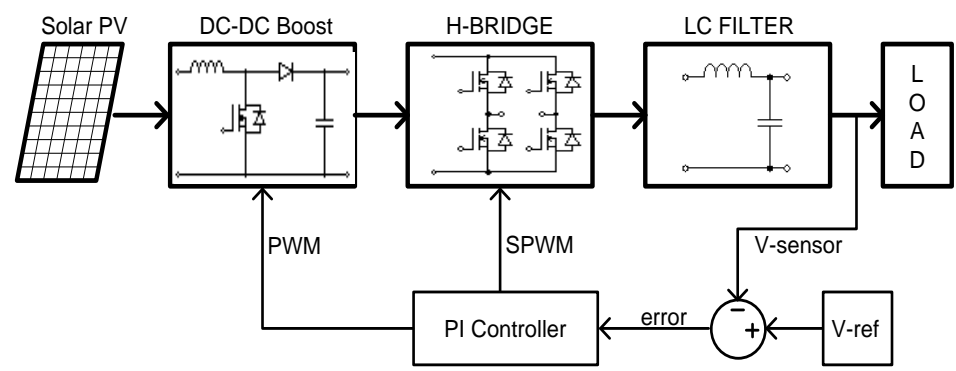

Figure 1. The block diagram of proposed system

\subsection{Solar PV}

In general, solar PV has an equivalent circuit and mathematical modeling according to $I$ - $V$ curve of ideal photovoltaic cell that required to know the parameters of solar panels used. A solar cell can be modeled by a current source connected in parallel with the diode. A shunt resistor $\left(R_{s h}\right)$ and a serie resistor $\left(R_{s}\right)$ added as the loss mechanism model in solar panel cells. The equivalent circuit of solar PV is as shown in Figure 2. 


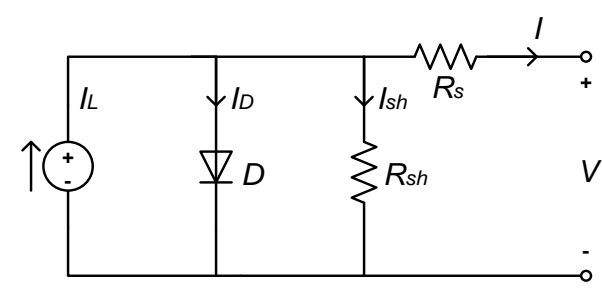

Figure 2. The equivalent circuit or solar PV

From the above equivalent circuit generated by a solar panel cell is the current source minus the current flowing through the diode and which flows through a shunt resistor, so it can be written the following equation:

$$
I=I_{L}-I_{0}\left[\exp \left(\frac{V+I R_{s}}{V_{t} a}\right)-1\right]-\frac{V+I R_{s}}{R_{s h}}
$$

where, $I_{L}$ is current generated due to light (A), $I_{0}$ is the saturation current of the p-n diode (A), $R_{s}$ is a series resistor of photovoltaic $(\mathrm{ohm}), R_{s h}$ is parallel of solar PV resistor $(\mathrm{ohm}), a$ is the parameter of diaoda $(1<a<2)$, and $V_{t}$ is terminal voltage $(\mathrm{V})$. The series configuration will produce a higher PV output voltage, which is the sum of all voltages of each cell. Conversely the parallel configuration will produce a higher PV output current [13]. Short circuit current $\left(I_{s c}\right)$ and open circuit voltage $\left(V_{o c}\right)$ are written by following equation:

$$
V_{o c}=V_{t}-I_{n}\left[\frac{I_{L}}{I_{s}}-1\right] \approx V_{t} \ln \left[\frac{I_{L}}{I_{s}}\right]
$$

the maximum power dissipated is as follow:

$$
P_{m}=V \times I=I_{s} V\left[e^{\frac{V}{V_{t}}}-1\right]-I_{L} V
$$

the maximum power will be achieved when $\frac{d P}{d V}=0$, so the maximum voltage and current can be written as follows:

$$
\frac{d P}{d V}=0=I_{s}\left[e^{\frac{V}{V t}}-1\right]-I_{L}+\frac{I_{s} V_{m}}{V_{t}} e^{\frac{V m}{V t}}
$$

\subsection{DC-DC boost}

DC-DC boost is a converter that works to increase the DC voltage to a higher level. This series of converter is widely applied to electronic devices to supply the load with a voltage higher than the source voltage. The basic concept of a boost converter circuit is addressed as in Figure 3.

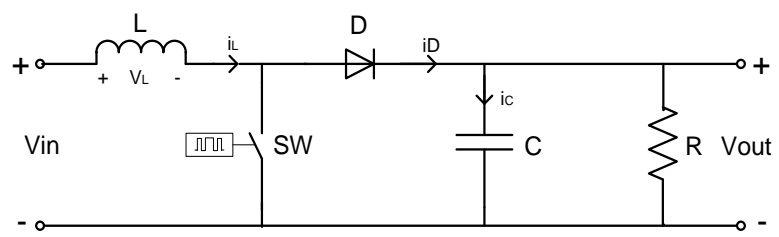

Figure 3. Basic circuit of DC-DC boost converter

when the switch is on, the inductor voltage is equal to the input voltage. Diode in reverse bias condition [14]. Inductors begin to store energy in the form of magnetic energy. The equation can be written as follows:

$$
V_{L}=V_{i n}=L \frac{d i L}{d t}
$$


when the swicth is off, the diode in forward bias. The energy stored on the inductor is passed through the diode to charge the capacitor and supply the load. The equation is as follows:

$$
\Delta i_{L, \text { off }}=\frac{\left(V_{\text {in }}-V_{\text {out }}\right)(1-D) T}{L}
$$

The process of energy absorption and discharging in the inductor is controlled by continuous switching cycle. This cycle consists of on and off which each duration is set to get the desired PWM [15]. The duration of the on condition in one period will determine the factor of voltage gain which is called the duty cycle $(D)$. Since the inductor current is constant, then from (6) and (7) is obtained:

$$
D=1-\frac{\text { Vin }}{\text { Vout }}
$$

next to determine the value of the selected inductor and capacitor can use the following equation $[16,17]$ :

$$
\begin{aligned}
& L=\frac{V_{\text {in }}\left(V_{\text {out }}-V_{\text {in }}\right)}{\Delta i_{L} \times f_{S} \times V_{\text {out }}} \\
& C=\frac{i_{\text {out }} \times D}{f_{S} \times \Delta V_{\text {out }}}
\end{aligned}
$$

\subsection{DC-AC inverter}

In off-grid and on-grid solar PV systems, DC-AC inverter (inverter) is common component needed to transmit DC energy from solar PV to AC loads. In the process of converting the dc voltage and current from $\mathrm{PV}$, the irradiation change becomes the disturbance factor so that the voltage and current generated by the inverter need to be optimized [18]. In this paper, the working principle of the single phase H-bridge VSI can be explained by the use of four power switches as shown in Figure 4.

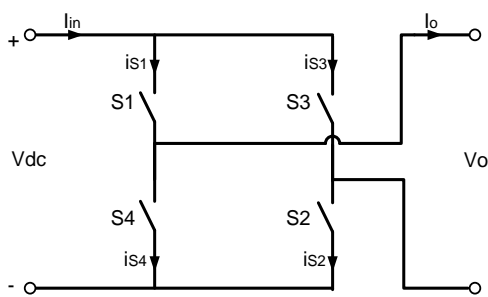

(a)

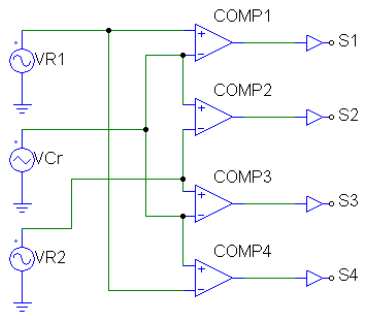

(b)

Figure 4. (a) Basic circuit of single phase Full bridge VSI, (b) SPWM driver circuit

The four power switches of H-bridge triggered by control circuit as a sub system integrated in inverter [19]. When the switches S1 and S2 in a condition on, the DC current will flow from left to right, if the switches S3 and S4 in a condition on, the DC current will flow from right to left. In this paper, the single phase of full-bridge VSI normally uses unipolar SPWM in converting DC into AC. Unipolar SPWM is obtained by comparing two sine waveforms as reference signals with different phase angle of $180^{\circ}\left(V_{R I}\right.$ and $\left.V_{R 2}\right)$ and high frequency of triangular waveform as carrier signal $\left(V_{C r}\right)$ [20-22]. Widths of the pulses $\left(V_{o}\right)$ are proportional to average value of the sinusoidal. Output pulses of this operation can be directly delivered to the switching devices of the full bridge VSI for generating the SPWM wave.

\subsection{LC filter}

The LC filter in this design was used to remove harmonic contents on the inverter output. Inductor and capacitor are arranged with frequency setting at the frequency of the harmonic voltage and the voltage ripple to be eliminated. The setting frequency can be written with the following equation:

$$
f_{r}=\frac{1}{2 \pi \sqrt{L C}}
$$


Based on the components $L$ and $C$, the characteristic impedance $\left(Z_{o}\right)$ can be determined by the following equation:

$$
Z_{o}=\sqrt{\frac{L}{C}}
$$

\subsection{Close loop controller voltage control mode}

The closed-loop control is a control system in which the output signals was censored and reversed into an input signal for the PI controller as shown in Figure 6.

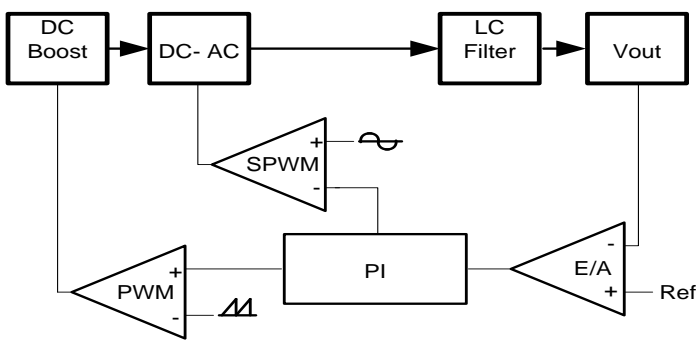

Figure 6. DC-AC inverter for voltage control model

In this design, to keep the expected output voltage remain constant, the DC-AC inverter was developed in closed-loop based on voltage control mode (VCM) operation [23-25]. The measured value and the reference voltage are compared to generate the control voltage. By using PI controller, the output voltage was adjusted by comparing the control voltage with the high frequency of the sawtooth waveform, so the duty ratio $(D)$ adjusts the desired voltage and produces the PWM output waveform. While in the DC-AC component, the output voltage is adjusted by comparing the control voltage with the low frequency of the sine waveform. Its will change the amplitude $\left(m_{a}\right)$ adjusts the desired voltage and produces the SPWM output waveform with setting frequency of $50 \mathrm{~Hz}$.

\section{RESULTS AND DISCUSSION}

The proposed design of the DC-AC inverter circuit is implemented using PSIM consists of solar PV, DC-DC boost, DC-AC inverting, filter, load and equipped with VCM close loop as shown in Figure 7.

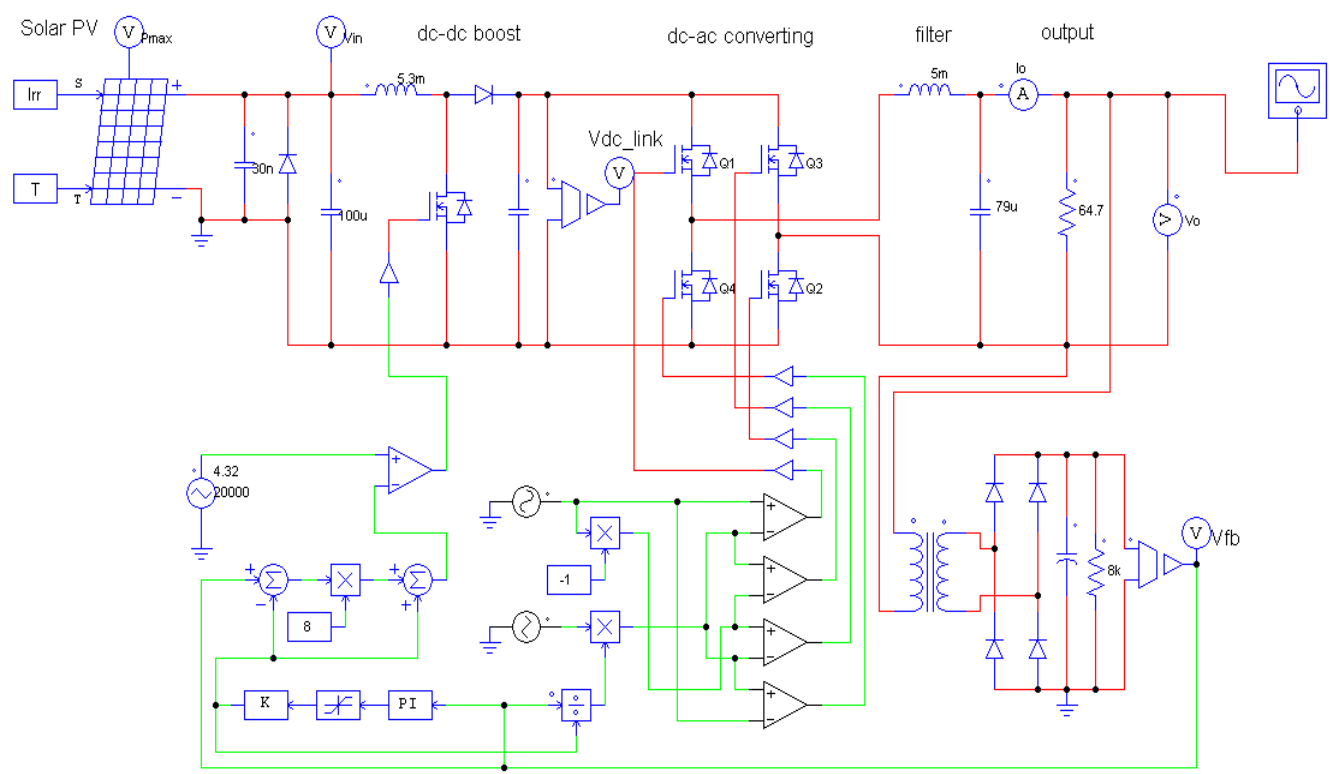

Figure 7. Proposed design circuit of DC-AC inverter 
The specification of solar PV is given Table 1:

Table 1. The spesification of solar PV (Sharp ND-130T1J), STC: $25^{\circ} \mathrm{C}, 1 \mathrm{~kW} / \mathrm{m}^{2}$, AM 1.5

\begin{tabular}{lc}
\hline \multicolumn{1}{c}{ Parameter } & Value \\
\hline Nominal Output $\left(P_{m}\right)$ & $130 \mathrm{Wp}$ \\
Open circuit voltage $\left(V_{o c}\right)$ & $22 \mathrm{Vdc}$ \\
Maximum power voltage $\left(V_{m}\right)$ & $17.4 \mathrm{Vdc}$ \\
Short circuit current $\left(I_{s c}\right)$ & $8.09 \mathrm{~A}$ \\
Maximum power current $\left(I_{m}\right)$ & $7.48 \mathrm{~A}$ \\
Tempeatur coefficient of $P_{m}$ & $-0.485 \% /{ }^{\circ} \mathrm{C}$ \\
Tempeatur coefficient of $I_{s c}$ & $0.053 \% /{ }^{\circ} \mathrm{C}$ \\
\hline
\end{tabular}

From the values of solar PV above specification parameters obtained power vs I-V curves at irradation of 600 and $1000 \mathrm{~W} / \mathrm{m}^{2}$ at $25^{\circ} \mathrm{C}$ according to STC standard as shown in Figure 8 .

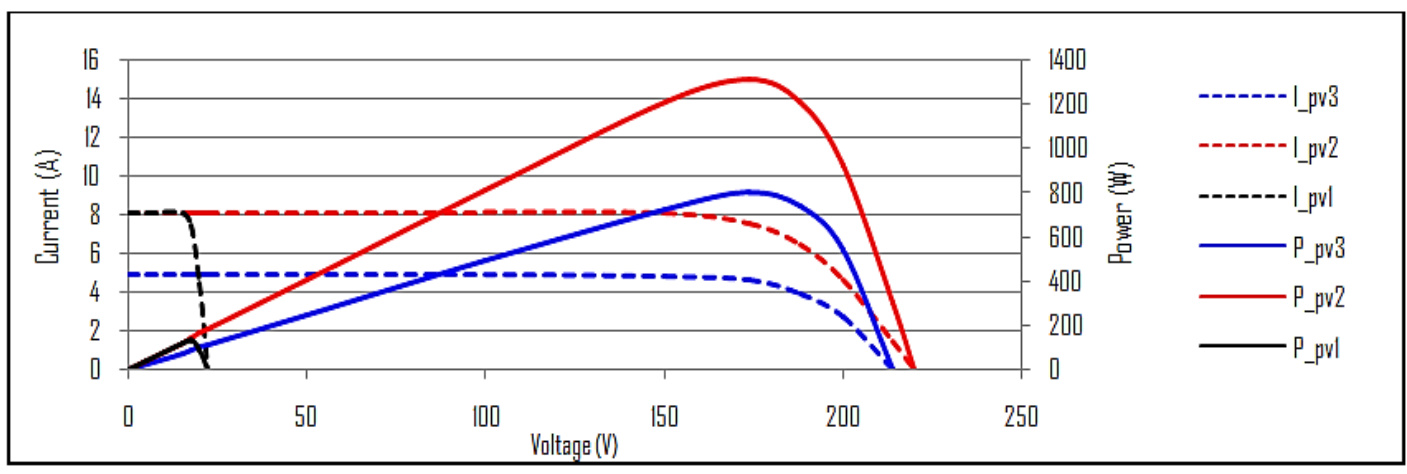

Figure 8. Power vs I-V curves of three solar PV configurations at STC standard

From Figure 8 it can be explained that $P_{-} p v 1$ is power vs I-V curves of single PV panel at 1000 $\mathrm{W} / \mathrm{m}^{2}, P_{-} p v 2$ is power vs $\mathrm{I}-\mathrm{V}$ curves of ten PV panels in series configuration at $1000 \mathrm{~W} / \mathrm{m}^{2}$, and $P \_p v 3$ is power vs I_V curves of ten PV panels in series configuration at $600 \mathrm{~W} / \mathrm{m}^{2}$. More detailed about the measurement results can be seen in Table 2:

Table 2. Measurement result of solar PV configurations

\begin{tabular}{cccccccc}
\hline Symbol & Number of panel & Configuration & $\begin{array}{c}\text { Irradiation } \\
\left(\mathrm{W} / \mathrm{m}^{2}\right)\end{array}$ & $\begin{array}{c}\text { Temp. } \\
\left({ }^{\circ} \mathrm{C}\right)\end{array}$ & $\begin{array}{c}P_{m} \\
(\mathrm{~W})\end{array}$ & $\begin{array}{c}V_{m} \\
(\mathrm{~V})\end{array}$ & $\begin{array}{c}V_{o c} \\
(\mathrm{~V})\end{array}$ \\
\hline$p v 1$ & 1 & single & 1000 & 25 & 125 & 17.4 & 21.9 \\
$p v 2$ & 10 & series & 1000 & 25 & 1250 & 174 & 219 \\
$p v 3$ & 10 & series & 600 & 25 & 762 & 165 & 214 \\
\hline
\end{tabular}

Since the required power is $746 \mathrm{~W}(1 \mathrm{HP})$, the matching voltage range at an irradiation of at least $600 \mathrm{~W} / \mathrm{m}^{2}$ is between $165-202 \mathrm{~V}$ corresponding to Figure 8 . This voltage range is then increased to $312 \mathrm{~V}$ to get the ac voltage (rms) $220 \mathrm{~V}$. The specification of DC-AC inverter completely is given Table 3:

Table 3. The spesification of DC-AC inverter

\begin{tabular}{lc}
\hline \multicolumn{1}{c}{ Parameter } & Value \\
\hline DC boost input voltage $\left(V_{i}\right)$ & $165-202$ to $312 \mathrm{Vdc}$ \\
AC output voltage $\left(V_{\text {oac }}\right)$ & $220 \mathrm{Vac}$ \\
AC output current $\left(I_{\text {oac }}\right)$ & $3.4 \mathrm{~A}$ \\
Load Impedance $\left(Z_{o}\right)$ & $64.7 \Omega$ \\
Output power rating $\left(P_{o}\right)$ & $746 \mathrm{~W}(1 \mathrm{HP})$ \\
Output frequency $\left(f_{o}\right)$ & $50 \mathrm{~Hz}$ \\
Switching frekuency $\left(f_{s}\right)$ & $20 \mathrm{kHz}$ \\
Duty range $(D)$ & $0.35-0.47$ \\
\hline
\end{tabular}


From Tabel 3, then design of DC-AC inverter was simulated by PSIM with variation of irradiation range $600-1500 \mathrm{~W} / \mathrm{m}^{2}$, and the results as shown as in Figure 9. It can be explained that the increase of irradiation from 600 to $1500 \mathrm{~W} / \mathrm{m}^{2}$ causes the resulting PV voltage also increased from 165 to $202 \mathrm{Vdc}$. This is because PV has linear characteristics between irradiation and voltage when connected load.

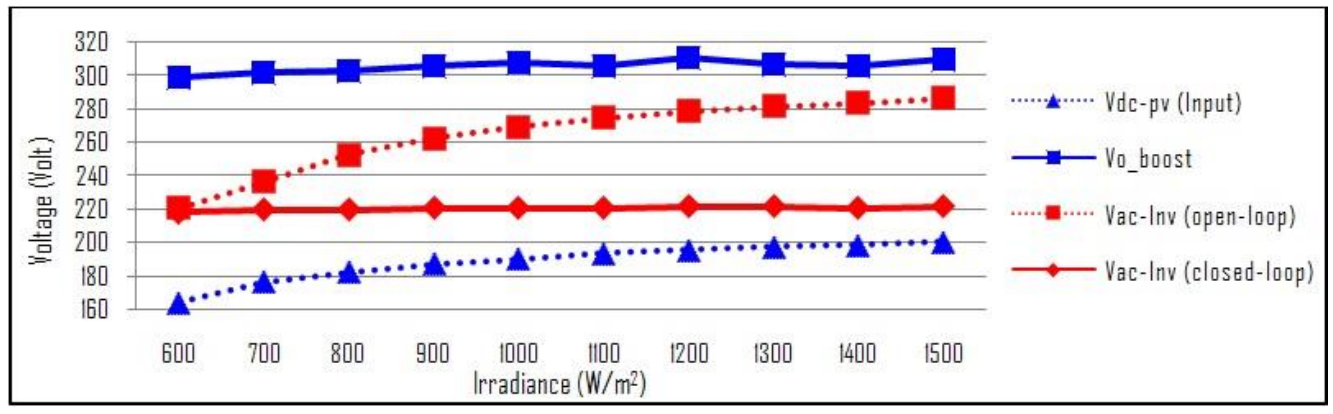

Figure 9. Simulation result of irradiation effect to input and ac output voltage (comparison of open loop \& closed loop)

However, the DC-AC inverter design using closed loop can maintain the output voltage between 218-221 Vac. The range is relatively constant at 220 Vac with an average error of $0.91 \%$ which is still within the permissible limits compared to open loop which tends to rise up from 220 to 286 Vac. The complete simulation results of the DC-AC inverter on three variations of solar PV irradiation to know the input voltage $\left(V_{i n}\right)$ and its waveform. Irradiation was set $600 \mathrm{~W} / \mathrm{m}^{2}$ during $0-0.2 \mathrm{~s}, 1000 \mathrm{~W} / \mathrm{m}^{2}$ from $0.2-0.4 \mathrm{~s}$, and $1500 \mathrm{~W} / \mathrm{m}^{2}$ from 0.4-0.6 s. At irradiation of $600 \mathrm{~W} / \mathrm{m}^{2}$, voltage of solar PV drops significantly due to loading from about $165 \mathrm{~V}$ to $129 \mathrm{~V}$, then rises to $169 \mathrm{~V}$ at $1000 \mathrm{~W} / \mathrm{m}^{2}$, and reaches $194 \mathrm{~V}$ at $1500 \mathrm{~W} / \mathrm{m}^{2}$ as shown in Figure 10 (a). From some changes of these input voltages, the dc-dc boost was managed to increase the changes in voltage to be relatively constant to $305 \mathrm{~V}$ ( $\left.V_{\text {o_boost }}\right)$. Figure 10 (b) shows the output voltage by open loop $\left(V_{o_{-}} O L\right)$ which tends to increase with increasing irradiation. While the output voltage of the closed loop $\left(V_{o_{-}} C L\right)$ using the PI controller remains constant at $220 \mathrm{~V}$ even input voltage changes due to irradiation changes.

The output voltage and current before and after filtering due to SPWM pulses is shown in Figure 11. Since SPWM is derived from switching techniques, this will cause distortion in the output waveform ( $V_{o \_}$unfiltering) as shown in Figure 11 (a). Here the use of LC filters has succeeded in fixing the distorted waveform, reducing harmonic ripple, and resulting in output waveforms of voltage and current being sinusoidal with frequency of $50 \mathrm{~Hz}$. Further, the initial voltage $\left(V_{o_{-}} O L\right)$ and initial current $\left(I_{o_{-}} O L\right)$ in the closed loop tends to be more stable than in the open loop as shown in Figure 10 (b) and Figure 11 (b). The use of PI controller in closed loop has been shown to be effective in improving offset, reducing overshoot and settling time.

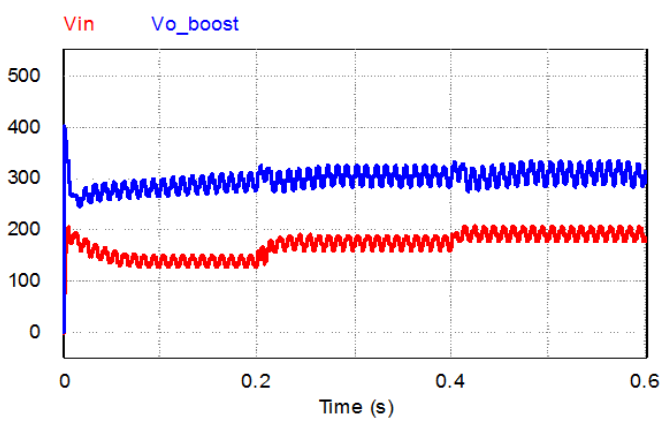

(a)

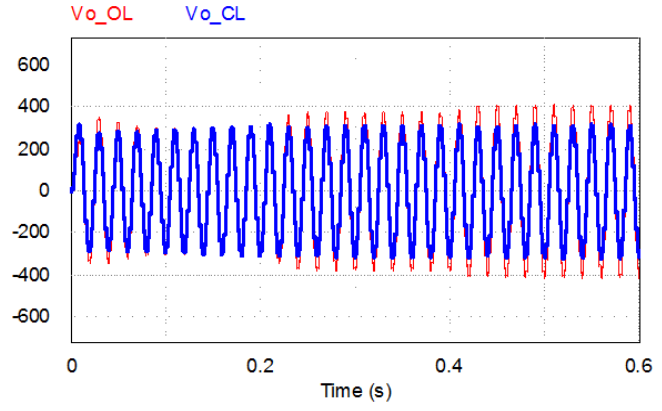

(b)

Figure 10. (a) Input voltage, (b) Comparison of output voltage between open loop (Vo_OL) and closed loop (Vo_CL) 


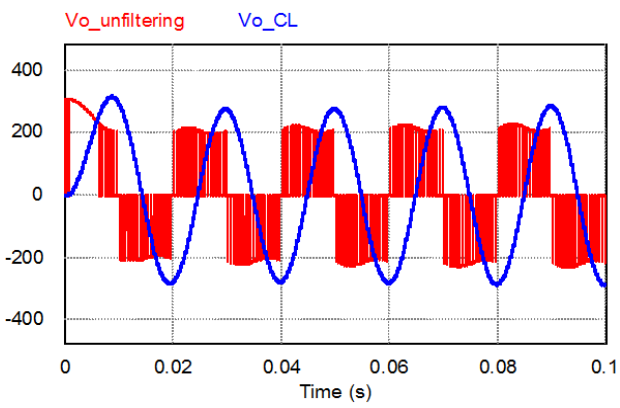

(a)

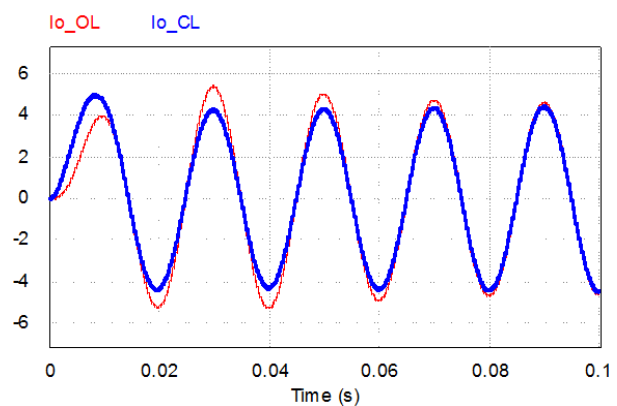

(b)

Figure 11. $50 \mathrm{~Hz}$ output waveform, (a) Voltage, (b) Current

According to efficiency calculations, that at $600 \mathrm{~W} / \mathrm{m}^{2}$ irradiance generates $754 \mathrm{~W}$ of solar PV and $737 \mathrm{~W}$ of DC-AC inverter output, its resulting maximum efficiency of $97.7 \%$. The minimum efficiency is $83.6 \%$ achieved at irradiation of $1500 \mathrm{~W} / \mathrm{m}^{2}$. The maximum efficiency of off-grid solar PV system will be achieved when the maximum power point (MPP) by solar PV equal to the required load power.

\section{CONCLUSION}

The design of the DC-AC inverter and its mathematical model was presented in this paper. The design was required to supply $746 \mathrm{~W}$ of AC loads with input sources connected directly to solar PV to eliminate the use of energy storage such as batteries. To ensure a constant output voltage, the design equipped by a close loop of voltage control mode. The simulation results performed by PSIM shows that the design was able to maintain the output voltage constant $(220 \mathrm{Vac}, 0.91 \%$ of error) matched with the electrical specifications of the load required even though the input voltage was variable due to irradiation changes of solar PV. Due to constant load power, the increasing power of solar PV from irradiation $600-1500 \mathrm{~W} / \mathrm{m}^{2}$ leads to a decrease in efficiency from 97.7-83.6\%. The design can be applied to supply the constant loads that only required during the day in off-grid solar power system.

\section{REFERENCES}

[1] V. V. Tyagi et al., "Progress in solar PV technology: Research and achievement," Renewable and Sustainable Energy Reviews, vol. 20, pp. 443-461, 2013.

[2] M. Gul et al., "Review on recent trend of solar photovoltaic technology," Energy Exploration \& Exploitation, vol. 34, no. 4, pp. 485-526, 2016.

[3] T. H. Loba and K. M. Salim, "Design and Implementation of a Micro-Inverter for Single PV Panel based Solar Home System," 2013 International Conference on Informatics, Electronics and Vision (ICIEV), Dhaka, pp. 1-5, 2013.

[4] Z. Zhou and J. Macaulay, "An Emulated PV Source Based on an Unilluminated Solar Panel and DC Power Supply," Enegies, vol. 10, no.12, pp. 1-20, 2017.

[5] D. Pal et al., "Central and Micro Inverters for Solar Photovoltaic Integration in AC grid," 2016 National Power Systems Conference (NPSC), Bhubaneswar, pp. 1-6, 2016.

[6] M. N. Hossain et al., "Design and Development of a Grid Tied Solar Inverter," 2012 International Conference on Informatics, Electronics \& Vision (ICIEV), Dhaka, pp. 1054-1058, 2012.

[7] S. S. Kumar et al., "A Voltage Controller in Photo-Voltaic System without Battery Storage for Stand-Alone Applications," International Conference on Electrical, Control and Computer Engineering 2011 (InECCE), Pahang, pp. 269-274, 2011.

[8] S. Chakraborty and M. A. Razzak, "Design of a Transformer-less Grid-Tie Inverter Using Dual-Stage Buck and Boost Converters," International Journal of Renewable Energy Research, vol. 4, no. 1, pp. 91-98, 2014.

[9] R. Akhter and A. Hoque, "Analysis of a PWM Boost Inverter for Solar Home Application," International Scholarly and Scientific Reseantific \& Innovation, vol. 2, no. 11, pp. 2626-2630, 2008.

[10] K. P. Rao et al., "Development of A Grid Connected Inverter for Solar PV Systems with Energy Capture Improvement Based On Current Control Strategy," International Journal of Scientific and Research Publications, vol. 3, no. 4, pp. 1-6, 2013.

[11] K. Arulkumar et al., "Recent Advances and Control Techniques in Grid Connected PV System-A Review," International Journal of Renewable Energy Research (IJRER), vol. 6, no. 3, pp. 1037-1049, 2016. 
[12] M. Errouha and A. Derouich, "Study and comparison results of the field oriented control for photovoltaic water pumping system applied on two cities in Morocco," Bulletin of Electrical Engineering and Informatics (BEEI), vol. 8, no. 4, pp. 1206-1212, 2019.

[13] B. Bhutia et al., "Design of PV Module for Green Building Installation," International Journal of Innovative Research in Science, Engineering and Technology, vol. 3, no. 4, pp. 11152-11158, 2014.

[14] S. W. Mohod and A. V. Padgavhankar, "Closed Loop Digital Controller of DC-DC Converter for Renewable Energy Source (PV Cell)," 2013 International Conference on Renewable Energy and Sustainable Energy (ICRESE), Coimbatore, pp. 112-116, 2013.

[15] S. Masri and P. W. Chan, "Design and Development of DC-DC Boost Converter with Constant Output Voltage," 2010 International Conference on Intelligent and Advanced Systems, Manila, pp. 1-4, 2010.

[16] B. Budiman et al., "Stabilization of Output Voltage with Feedback Circuit and Filter on 2 Stages-Step up Converter (24V to 312V DC)," The 2nd Annual Applied Science and Engineering Conference (AASEC 2017), IOP Conf. Series: Materials Science and Engineering, vol. 288, pp. 1-6, 2017.

[17] M. H. Rashid, "Power Electronics," New Delhi, India: Prentice-Hall of India Private Limited, pp. 147-265, 2007.

[18] N. Ismail et al., "The Effect of Amplitude Modulation Index and Frequency Modulation Index on Total Harmonic Distortion in 1-Phase Inverter," The 2nd Annual Applied Science and Engineering Conference (AASEC 2017), IOP Conf. Series: Materials Science and Engineering, vol. 288, 2017.

[19] R. Muhida et al.,"Design of a DC-AC Link Converter for 500W Residential Wind Generator," Journal of Mechatronics, Electrical Power, and Vehicular Technology, vol. 3, pp. 95-102, 2012.

[20] S. H. Pawar et al.,"Effect of Carrier Frequency on the Performance of Three Phase SPWM Inverter," International Journal of Science, Engineering and Technology Research, vol. 4, no. 9, pp. 3019-3023, 2015.

[21] A. Namboodiri and H. S. Wani,"Unipolar and Bipolar PWM Inverter," International Journal for Innovative Research in Science \& Technology, vol. 1, no. 7, pp. 237-243, 2014.

[22] S. Maheshri and P. Khampariya,"Simulation of single phase SPWM (Unipolar) inverter," International Journal of Innovative Research in Advanced Engineering, vol. 1, no. 9, pp. 12-18, 2014.

[23] Suwarno and T. Sutikno,"Implementation of buck-boost converter as low voltage stabilizer at $15 \mathrm{~V}$," International Journal of Electrical and Computer Engineering (IJECE), vol. 9, no. 4, pp. 2230-2237, 2019.

[24] A. Kalirasu and S. S. Dash, "Simulation of Closed Loop Controlled Boost Converter for Solar Installation," Serbian Journal of Electrical Engineering, vol. 7, no. 1, pp. 121-130, 2010.

[25] S. Kasbi et al., "Design and Implementation of Controller for Boost DC-DC Converter Using PI-LPF Based on Small Signal Model," Journal of Mechatronics, Electrical Power, and Vehicular Technology, vol. 6, no. 2, pp. 105-112, 2015. 